\title{
Pengaruh Kecerdasan Emosional dan Adversity Quotient terhadap Kemampuan Pemecahan Masalah Matematika Siswa SDIT IQRA'1 Kota Bengkulu
}

\author{
Merianah \\ Guru SD IT Iqra' 2 Bengkulu
}

\begin{abstract}
Abstrak
Penelitian ini bertujuan untuk mengetahui pengaruh langsung dan tidak langsung antara kecerdasan emosional, adversity quotient terhadap kemampuan pemecahan masalah matematika.Metode yang digunakan dalam penelitian ini adalah metode survey dengan pendekatan kuantitatif yang dilakukan di SDIT IQRA' 1 Kota Bengkulu tahun pelajaran 2017/2018 di kelas IV. Pengumpulan data dilakukan melalui dokumentasi dan instrument berupa kuesioner dan tes pemecahan masalah. Data hasil tes dianalisis menggunakan uji analisis jalur dengan taraf signifikansi 5\%. Hasil penelitian menunjukkan ada pengaruh langsung positif secara signifikan antara kecerdasan emosi, Adversity quotient, kecerdasan emosional, serta kecerdasan emosi terhadap Adversity quotient.
\end{abstract}

Kata kunci: Kecerdasan Emosional, Adversity Quotient, dan kemampuan Pemecahan Masalah

\section{Pendahuluan}

Pembelajaran matematika dikenalkan mulai dari usia dini sampai pada tingkat perguruan tinggi. Hal ini disebabkan karena matematika dapat digunakan secara luas dalam segala bidang kehidupan manusia, seperti dalam ilmu pengetahuan dan teknologi.Namun tidak sedikit orang yang beranggapan bahwa matematika itu merupakan pelajaran yang sulit, sehingga siswa merasa takut terlebih dahulu kepada pelajaran matematika, siswa menganggap pelajaran matematika menyeramkan, sangat sulit, bahkan ada yang mengatakan bahwasannya matematika merupakan pelajaran yang sangat mereka benci.sehingga banyak sekali siswa yang tidak percaya akan dirinya sendiri, hal ini terlihat dari tingkah laku siswa saat mengerjakan soal-soal matematika baik itu saat latihan ataupun saat ulangan, banyak siswa yang meragukan kemampuannya sehingga ia cenderung melihat kekanan dan kekiri, mencontek atau bertanya kepada temannya. Hal ini disebabkan karena siswa cepat berputus asa atau mudah menyerah dalam menyelesaikan permasalahan yang diberikan, siswa cenderung tidak memiliki daya juang saat belajar matematika, terlihat dari rasa malas dalam mengikuti pelajaran matematika dan kondisi emosional siswa saat belajar matematika cenderung tertekan atau tidak stabil mengakibatkan semakin bertambahnya ketidaksukaan siswa terhadap pembelajaran matematika. Hasil survei awal yang dilakukan penulis sebagai guru SDIT IQRA'1 kota Bengkulu di temukan siswa yang cenderung emosinya tertekan saat belajar matematika, tidak tampaknya daya juang siswa dalam menyelesaikan masalah-masalah dalam belajar matematika.

Keberhasilan siswa dalam pembelajaran tergantung pada bagaimana carasiswa mengatasi kesulitan yang ada.Di kehidupan ini termasuk dalam dunia pendidikan, merupakan hal wajar apabila ada siswa yang memiliki tingkat 
kecerdasan yang lebih tinggi dibandingkan siswa lainnya.Kecerdasan dipandang sebagai sebagai sesuatu yang relatif, sebab kecerdasan setiap individu berbedabeda. Jika dikaitkan dengan cara mengatasi kesulitan, maka jenis kecerdasan yang digunakan adalah adversity quotient. Adversity quotient merupakan kecerdasan individu dalam mengatasi setiap kesulitan yang muncul.Adversity quotient sering diindentikkan dengan daya juang untuk melawan kesulitan.Sri Wardhani (2010: 22) mengemukakan bahwa pemecahan masalah adalah suatu proses menerapkan pengetahuan yang telah diperoleh sebelumnya ke dalam situasi baru yang belum dikenal. Dengan adanya kemampuan memecahkan masalah matematika diharapkan mampu meningkatkan hasil belajar matematika siswa baik berupa ranah kognitif, afektif, maupun psikomotor.

Berdasarkan uraian permasalahan di atas, peneliti tertarik untuk mengadakan suatu penelitian yang berjudul Pengaruh Kecerdasan Emosional, Adversity Quotient terhadap kemampuan pemecahan masalah matematika siswa SDIT IQRA’ 1 di Kota Bengkulu.

\section{Metode Penelitian}

Jenis penelitian ini adalah penelitian deskripftif dan verifikatif.. Metode penelitian yang di gunakan adalah metode survay.

Penelitian ini di lakukan di SDIT IQRA' 1 Kota Bengkulu. Yang terletak di jalan Semeru no 22 Kelurahan Sawah Lebar Kecamatan Ratu Agung.

Waktu Penelitian direncanakan selama 4 bulan yang di mulai dari proses perencanaan hingga proses pelaporan selesai terhitung dari bulan desember 2017 sampai maret 2018 dengan alokasi pembagian waktu yang dapat dilihat pada tabel di bawah ini

Populasi dalam penelitian ini adalah seluruh siswa kelas 4 SDIT IQRA'1Kota Bengkulu. Berdasarkan data dari SDIT IQRA 1 maka setelah di hitung berdasarkan rumus diperoleh jumlah sampel penelitian ini $n=63$.

Variabel dalam penelitian ini terdapat 3 variabel laten, yaitu kecerdasan emosional dan adversity quotient, terhadap kemampuan pemecahan masalah,dalam penelitian ini yang menjadi variabel independen atau eksogen adalah kecerdasan emosi $\left(X_{1}\right)$ (b) Variabel Endogen. Sugiyono(2007:4). Dalam penelitian ini variabel endogen antara lain : adversity quotient $\left(X_{2}\right)$, dan kemampuan pemecahan masalah (Y) .

Teknik pengumpulan data yaitu studi dokumentasi dan teknik instrumen. Instrumen yang digunakan dalam bentuk model skala Likert. Item-item dalam skala ini merupakan pernyataan/soal dengan lima pilihan jawaban.

\section{Hasil Dan Pembahasan Penelitian}

Dari data yang diperoleh, dapat dideskripsikan distribusi masing-masing variabel. Pengelompokkan data, distribusi frequensi, rata-rata, simpangan baku, median, mode, standar deviation, variance, range, minimum, maximum.

Skor kecerdasan emosi diperoleh skor terendah 30 dan skor tertinggi 62 dengan rentangan 32. Total skor tersebut diperoleh dari 17 butir pertanyaan. Jumlah skor teoritik minimal dan maksimal yang mungkin terjadi adalah 17 dan 85. nilai rata-rata $=52,84$, simpangan baku $=7,003$ dan varian $=49,039$. 
Skor adversity Quotient diperoleh skor terendah 28 dan skor tertinggi 62 dengan rentangan 34. Total skor tersebut diperoleh dari 16 butir pertanyaan. Jumlah skor teoritik minimal dan maksimal yang mungkin terjadi adalah 16 dan 80. Nilai rata-rata $=52,064$, simpangan baku $=7,590$ dan varian $=57,609$

Skor kemampuan pemecahan masalah diperoleh skor terendah 28 dan skor tertinggi 60 dengan rentangan 32. Total skor tersebut diperoleh dari 12 butir pertanyaan. Jumlah skor teoritik minimal danm maksimal yang mungkin terjadi adalah 24 dan 60. nilai rata-rata $=51,841$ simpangan baku $=7,058$ dan varian $=$ 49,813 .

Hasil normalitas Asymp.Sig.(2-tailed) masing-masing variabel memiliki nilai probabilitas $>0,05$. Kecerdasan emosi $=0,205>0,05$. Adversity quotient $=0,423$ $>0,05$. Dan kemampuan pemecahan masalah $=0,217>0,05$. Berdasarkan perhitungan tersebut dapat disimpulkan bahwa populasi masing-masing variabel berdistribusi normal.

Berdasarkan analisis tabel anava di atas nilai $\mathrm{F}_{\text {hitung }}$ deviation from linierity untuk pasangan uji variabel kemampuan pemecahan masalah (Y) atas variabel kecerdasan emosi $\left(\mathrm{X}_{1}\right)$ diperoleh nilai nilai $[\operatorname{sig}=0,085]>[\alpha=0,05]$. Disimpulkan bahwa distribusi pasangan uji variabel kemampuan pemecahan masalah $(\mathrm{Y})$ atas variabel kecerdasan emosi $\left(\mathrm{X}_{1}\right)$ distribusi berpola liniear.

Sedangkan nilai $\mathrm{F}_{\text {hitung }}$ deviation from linierity untuk pasangan uji variabel kemampuan pemecahan masalah (Y) atas variabel adversity quotient $\left(\mathrm{X}_{2}\right)$ diperoleh nilai nilai $[\operatorname{sig}=0,104]>[\alpha=0,05]$.Sehingga dapat disimpulkan bahwa distribusi pasangan uji variabel kemampuan pemecahan masalah (Y) atas variabel adversity quotient $\left(\mathrm{X}_{2}\right)$ distribusi berpola liniear.

Uji deviation from linierity untuk pasangan uji variable Adversity quotient $\left(\mathrm{X}_{2}\right)$ atas variabel kecerdasan emosi $\left(\mathrm{X}_{1}\right)$ diperoleh nilai nilai $[\operatorname{sig}=0,538]>$ $[\alpha=0,05]$. Sehingga dapat disimpulkan bahwa distribusi pasangan uji variable Adversity quotient $\left(\mathrm{X}_{2}\right)$ atas variabel kecerdasan emosi $\left(\mathrm{X}_{1}\right)$ distribusi berpola liniear.

Hasil perhitungan diperoleh nilai $\mathrm{F}_{\text {hitung }}=1,0153$ dengan nilai probabilitas (sig. $)=0,000$. Karena $[($ sig. $)=0,000]<.[\alpha=0,05]$, maka keputusannya adalah $\mathrm{H}_{0}$ ditolak dan $\mathrm{H}_{1}$ diterima artinya kecerdasan emosi (X1) secara bersamasama maupun individual berpengaruh langsung positif terhadap dan adversity quotient (X2). Dengan demikian model substruktur 3 yang dinyatakan teruji.

Koefisien jalur (X1) terhadap (X2) atau $\boldsymbol{\beta} \times 2 \times 1=0,971$ dengan nilai $t_{\text {hitung }}=$ 31,863 dan sig. $=0,000$, Seluruh Koefisien residu $\left(\varepsilon_{3}\right)$ dihitung berdasarkan model output Model Summary, yaitu :

$\varepsilon_{1}=\sqrt{1-R_{Y}^{2}}=\sqrt{1-0,943}=0,239$. Berdasarkan koefisien jalur tersebut, maka persamaan jalurnya dapat dibuat sebagai berikut:

$$
\mathrm{Y}=\beta_{\mathrm{x} 2 \times 1} \mathrm{X}_{1}+\varepsilon_{3}=1,053 \mathrm{X} 1+0,239
$$

Besarnya pengaruh bersama-sama variable (X1) terhadap variable (X2) dilihat dari koefisien determinasi $\mathrm{R}_{\text {square }}=0,943$ atau $94,3 \%$ dan besarnya pengaruh variabel lain adalah $(\sqrt{1-0,943})^{2}=0,057$ sebesar $5,7 \%$.

Setelah dilakukan analisis model struktur kausal, hasil perhitungan yang diperoleh digunakan untuk menguji hipotesis berikut: 
a. Kemampuan kecerdasan emosi (X1) berpengaruh langsung positif terhadap kemampuan pemecahan masalah (Y)

Hipotesis statistik yang diajukan sehubungan dengan Kemampuan kecerdasan emosi (X1) berpengaruh langsung positif terhadap kemampuan pemecahan masalah (Y) adalah:

$\mathrm{H}_{0} \quad$ : $\boldsymbol{\beta} \mathbf{Y X} 1 \leq \mathbf{0}$

$\mathrm{H}_{1} \quad: \boldsymbol{\beta} \mathbf{Y X 1}>\mathbf{0}$

Dari hasil perhitungan nilai koefisien jalur dengan $\boldsymbol{\beta Y X 1}_{\mathbf{X}} \mathbf{0 , 2 6 6} \mathrm{t}_{\text {hitung }}=3,158$ dan Sig. $=0,003$, sedangkan nilai $t_{\text {tabel }}=2,001$ pada $\alpha=0,05$ dengan derajat kebebasan $(\mathrm{dk})=59$. Oleh karena itu $t_{\text {hitung }}=3,158$ lebih besar dari $t_{\text {tabel }}=$ 2,001 dan Sig. $=0,003$ lebih kecil $\alpha=0,05$, maka koefisien jalur adalah signifikan.

b. Kemampuan adversity quotient (X2) berpengaruh langsung positif terhadap kemampuan pemecahan masalah (Y)

Hipotesis statistik yang diajukan sehubungan dengan Kemampuan adversity quotient (X2) berpengaruh langsung positif terhadap kemampuan pemecahan masalah (Y) adalah:

$\mathrm{H}_{0} \quad: \boldsymbol{\beta} \mathbf{Y X 2} \leq \mathbf{0}$

$\mathrm{H}_{1} \quad$ : $\boldsymbol{\beta} \mathbf{Y X 2}>\mathbf{0}$

Dari hasil perhitungan nilai koefisien jalur dengan $\boldsymbol{\beta}_{\mathbf{Y X 2}}=0,456, \mathrm{t}_{\text {hitung }}=5,247$ dan Sig. $=0,000$, sedangkan nilai $t_{\text {tabel }}=2,001$ pada $\alpha=0,05$ dengan derajat kebebasan $(\mathrm{dk})=59$. Oleh karena itu $t_{\text {hitung }}=5,247$ lebih besar dari $t_{\text {tabel }}=$ 2,001 dan Sig. $=0,000$ lebih kecil $\alpha=0,05$, maka koefisien jalur adalah signifikan.

c. Kemampuan kecerdasan emosi (X1) berpengaruh langsung positif terhadap adversity quotient (X2)

Hipotesis statistik yang diajukan sehubungan dengan Kemampuan kecerdasan emosi (X1) berpengaruh langsung positif terhadap adversity quotient (X2) adalah:

$\mathrm{H}_{0} \quad: \boldsymbol{\beta} \mathbf{x} 2 \mathbf{X} 1 \leq \mathbf{0}$

$\mathrm{H}_{1} \quad: \boldsymbol{\beta} \times 2 \times 1>0$

Dari hasil perhitungan nilai koefisien jalur $\boldsymbol{\beta} \mathbf{x} \mathbf{2} \mathbf{x} \mathbf{1}=0,971$ dengan $t_{\text {hitung }}=$ 31,863 dan Sig. $=0,000$, sedangkan nilai $t_{\text {tabel }}=2,000$ pada $\alpha=0,05$ dengan derajat kebebasan $(\mathrm{dk})=61$. Oleh karena itu $t_{\text {hitung }}=31,863$ lebih besar dari $t_{\text {tabel }}=2,000$ dan Sig. $=0,000$ lebih kecil $\alpha=0,05$, maka koefisien jalur adalah signifikan.

\section{Simpulan}

1. Kecerdasan emosional berpengaruh langsung terhadap kemampuan pemecahan masalah matematika dengan nilai koefisien jalur dengan $\boldsymbol{\beta}_{\mathbf{Y X 1}=\mathbf{0 , 2 6 6}} \mathrm{t}_{\text {hitung }}=$ 3,158 dan Sig. $=0,003$, sedangkan nilai $t_{\text {tabel }}=2,001$ pada $\alpha=0,05$ dengan derajat kebebasan $(\mathrm{dk})=59$. Oleh karena itu $t_{\text {hitung }}=3,158$ lebih besar dari $t_{\text {tabel }}=2,001$ dan Sig. $=0,003$ lebih kecil $\alpha=0,05$. Simpulan ini memperkuat teori yang menyatakan bahwa semakin tinggi kecerdasan emosi yang dimiliki oleh seorang siswa, 
maka akan semakin tinggi pula kemampuan pemecahan masalah matematika yang terdapat dalam diri siswa.

2. Adversity quotient berpengaruh langsung terhadap kemampuan pemecahan masalah matematika dengan nilai koefisien jalur dengan $\boldsymbol{\beta}_{\mathbf{Y X} 2=} 0,456, \mathrm{t}_{\text {hitung }}=5,247$ dan Sig. $=$ 0,000 , sedangkan nilai $\mathrm{t}_{\text {tabel }}=2,001$ pada $\alpha=0,05$ dengan derajat kebebasan $(\mathrm{dk})=$ 59. Oleh karena itu $t_{\text {hitung }}=5,247$ lebih besar dari $t_{\text {tabel }}=2,001$ dan Sig. $=0,000$ lebih kecil $\alpha=0,05$, Simpulan ini memperkuat teori yang menyatakan bahwa semakin tinggi daya juang (adversity quotient ) yang dimiliki oleh seorang siswa, maka akan semakin tinggi pula kemampuan pemecahan masalah matematika yang terdapat dalam diri siswa.

3. Kecerdasan emosional pengaruh langsung terhadap adversity quotient dengan koefisien jalur $\boldsymbol{\beta}_{\mathbf{X} 2 \times 1}=0,971$ dengan $t_{\text {hitung }}=31,863$ dan Sig. $=0,000$, sedangkan nilai $t_{\text {tabel }}=$ 2,000 pada $\alpha=0,05$ dengan derajat kebebasan $(\mathrm{dk})=61$. Oleh karena itu $\mathrm{t}_{\text {hitung }}=$ 31,863 lebih besar dari $t_{\text {tabel }}=2,000$ dan Sig. $=0,000$ lebih kecil $\alpha=0,05$. Simpulan ini memperkuat teori yang menyatakan bahwa semakin tinggi kecerdasan emosi yang dimiliki oleh seorang siswa maka akan semakin tinggi pula daya juang ( adversity quotient dalam diri siswa tersebut.

\section{Daftar Bacaan}

Abdurrahman, M. 2009. Pendidikan Bagi Anak Berkesulitan Belajar. Jakarta: Rineka Cipta

Afriansyah, E.A. Muna, D.N. 2016.Peningkatan Kemampuan Pemahaman Matematis Siswa melalui Pembelajaran Kooperatif Teknik Kancing Gemerencing dan Number Head Together.Jurnal Pendidikan Matematika STKIP Garut Vol. 8.No.3 (hal 34-39).

Ahmad, R.A. 2016. pengaruh math phobia, self-efficacy, adversity quotient dan motivasi berprestasi terhadap prestasi belajar matematika siswa SMP. Jurnal riset pendidikan Matematika Universitas Yogyakarta Vol. 3. No.2 (259-272).

Anita, W.I. 2014. Pengaruh Kecerdasan Emosional (mathematics anxiety) terhadap kemampuan koneksi matematis siswa smp.Infinity jurnal ilmiah progam study pendidikan matematika STKIP Siliwangi Bandung Vol. 3. No. 1 ( 125-132).

Arikunto, S. 2010. Prosedur Penelitian . Jakarta: Rineka Cipta

Ashcraft, M.H. 2002. "Math Anxiety: Personal, Educational, and Cognitive Consequences". Directions in Psychological Science. 11.

Chatarina, Anni 2004. Psikologi Belajar. Semarang : UNNES PRES

Dewi Herawaty. 2013.Pengaruh Kecerdasan Emosional, Partisipasi Guru dalam Forum Ilmiah, Keyakinan Diri (Self Efficacy), dan Motivasi Kerja terhadap Kinerja Guru Matematika (Studi Kausal di SMP Negeri se-Provinsi Bengkulu. Disertasi Doktor: UNJ

Djiwandono, Sri Esti Wuryani 2002. Psikologi Pendidikan. Jakarta : PT Gramedia Widiasarana Indonesia.

Eddy Izwanto. 2013. Pengaruh Self Efficacy, Kemampuan Pemahaman Konsep, Kemampuan Berpikir Kreatif, terhadap Kemampuan Pemecahan Masalah serta Dampaknya Terhadap Hasil Belajar Matematika. Tesis: Prodi Pendidikan Matematika FKIP Unib 
Efendi, A. 2005.Revolusi Kecerdasan Abad 21: Kritik MI, EI, SQ, AQ, dan Successful Intelligence Atas IQ. Bandung: Alfabeta.

Ghozali, I. 2011. Konsep dan aplikasi dengan program AMOS 22.0: update bayesian SEM. Semarang: Badan Penerbit Universitas Diponegoro

Hasbulah. 2012. Pengaruh komunikasi keluarga dan kemampuan awal ipa terhadap prestasi belajar IPA. Jurnal Formatif. 2 (1): 45-57

Hendriana, H dan Soemarmo, U. 2010. Penilaian Pembelajaran Matematika. Bandung: PT. Refika Aditama.

Johnson, D. 2003. Math Anxiety.Literature Review.

Kurniawati, D.A. 2014. Pengaruh kecemasan dan self efficacy siswa terhadap kemampuan pemecahan masalah materi segiempat siswa kelas VII Mts Negeri Ponorogo, mathedhunesa jurnal ilmiah matematika, vol 3, no 2.

Lestari, E.K, Mokhammad Ridwan. 2015. Penelitian Pendidikan Matematika. Bandung:PT Refika Aditama.

Lunenburg, F.C. 2011. Self efficacy in the workplace: implication for motivation and performance. International Journal of Management, Bussiness, and Administration, vol 14 , no 1

Peker, M. 2009."Pre-Service Teachers' Teaching Anxiety about Mathematics and Their Learning Styles".Eurasia Journal of Mathematics, Science, \&Technology Eductaion. 5 (4), 335-345.

Qohar, A. 2009.Pemahaman Matematis Siswa Sekolah Menengah Pertama pada Pembelajaran dengan Model Reciprocal Teaching.Makalah padaSeminar Nasional Matematika danPendidikan Matematika JurusanPendidikan Matematika FMIPAUNY (P-31).

Riduwan, 2013.Belajar mudah penelitian untuk guru karyawan dan peneliti pemula.Bandung : Alfabeta.

Riduwan dan Kuncoro.2006 . Cara Menggunakan dan Memaknai Analisis Jalur ( path analysis ). Bandung : Alfabeta.

Sardiman, A.M. 2007. Interaksi dan Motivasi Belajar Mengajar. Jakarta: Cipta Prakasa Sejati

Stoltz, P.G. 2000. Adversity Quotient: Mengubah Hambatan Menjadi Peluang. Terjemahan: T. Hermaya. Jakarta: Gramedia Widiasarana Indonesia.

Sudarman. 2012. Adversity Quotient: Kajian Kemungkinan Pengintegrasiannya dalam Pembelajaran Matematika. Jurnal Pendidikan Matematika AKSIOMA Vol. 1.No.1 (hal 55-62).

Sugiyana. 2015. Pengaruh Self-Regulated Learning, Self-Efficacy dan Perhatian Orangtua Terhadap Prestasi Belajar Matematika Siswa. psikopedagogia vol 4. No. 1.

Sugiyono. 2013. Metode penelitian kuantitatif, kualitatif dan $R \& D$. Bandung: Alfabeta

Sugiyono. 12015. Cara mudah menyusun skripsi, thesis, dan desertasi. Bandung: Alfabeta.

Syah, M. 2010. Psikologi Belajar. Jakarta: Rajagrafindo Persada. 
Sugihartono, dkk. 2007. Psikologi Pendidikan Yogyakarta: UNY Press.

Supardi, U.S. 2013. Pengaruh adversity quotient terhadap prestasi belajar siswa.Jurnal formatif UNINDRA Vol. 3. No. 1 (61-71)

Wahyudin. 2010. Monograf: Kecerdasan Emosional. Bandung: Program Studi Pendidikan Matematika SPS UPI.

Widoyoko, E. P. 2009. Evaluasi program pembelajaran. Yogyakarta: Pustakal Pelajar.

Zakaria, E., Nordin, N. M. 2008. "The Effects of Mathematics Anxiety on Matriculation Student as Related to Motivation and Achievement".Eurasia Journal of Mathematics, Science, \& Technology Eductaion. 4 (1), 27-30.

Zimmerman, B. J. 2000. Self efficacy: an essential motive to learn. Contemporary Educational Psychology 25, 82-91. Graduate School and University Center of City University of New York. 